\title{
Pemanfaatan Lingkungan Sekitar Sekolah Sebagai Sumber Belajar Untuk Meningkatkan Aktivitas Dan Hasil Belajar Siswa Sekolah Dasar Negeri 5 Bengkulu Tengah
}

\author{
Atika Sari ${ }^{1}$ dan Veronica Siti Suwarni ${ }^{2}$ \\ ${ }^{1}$ Sekolah Menengah Atas Negeri 7 Kota Bengkulu \\ Jalan Sadang Nomor 1 Kel. Lingkar Barat Kota Bengkulu \\ ${ }^{2}$ Sekolah Dasar Negeri 5 Bengkulu Tengah \\ J1. Raya Bukit Sunur Taba Lagan Talang Empat Kabupaten Bengkulu Tengah \\ Email : ${ }^{*}$ atikasari768@gmail.com
}

\begin{abstract}
ABSTRAK
Penelitian ini bertujuan untuk melihat peningkatan aktivitas dan hasil belajar siswa di kelas VI Sekolah Dasar Negeri 5 Bengkulu Tengah melalui pembelajaran menggunakan metode inkuiri dengan pemanfaatan lingkungan sekolah adapun jenis penelitian ini adalah penelitian tindakan kelas yang terdiri dari 4 tahapan yaitu tahap perencanaan, tahap pelaksanaan tindakan, tahap observasi dan tahap refleksi. Untuk hasil observasi guru pada siklus I di peroleh skor rata-rata 27 aktiviras guru dengan kriteria cukup meningkat pada siklus II sebesar 30 dengan kriteria baik meningkat kembali pada siklus III sebesar 34 dengan kriteria baik. Sedangkan skor ratarata aktivitas siswa pada siklus I sebesar 26 dengan kriteria cukup meningkat pada siklus II sebesar 29 dengan kriteria baik meningkat kembali pada siklus III sebesar 31 dengan kriteria baik. persentase ketuntasan hasil belajar pada siklus 65,38\% (belum tuntas) meningkat pada siklus II 76,92\% (belum tuntas) meningkat kembali pada siklus III 88,46\% (tuntas). Untuk penilaian aktivitas guru dan siswa menggunakan lembar observasi, sementara itu penilaian tes dianalisis dengan lembar tes tertulis. Dari hasil analisa yang telah dilakukan, maka pembelajaran menggunakan metode inkuiri dengan pemanfaatan lingkungan sekolah dapat meningkatkan aktivitas guru dan siswa, hasil belajar siswa SD Negeri 5 Bengkulu Tengah.
\end{abstract}

Kata kunci : Aktivitas, Hasil Belajar, inkuiri, Sekolah Dasar.

\section{PENDAHULUAN}

Undang-Undang RI Nomor 20 Tahun 2003 mendefenisikan pendidikan adalah usaha sadar dan terencana untuk mewujutkan suasana belajar dan proses pembelajaran sehingga peserta didik secara aktif mengembangkan potensi dirinya untuk memeiliki kekuatan spiritual keagamaan, pengendalian diri, kepribadian, kecerdasan, akhlak mulia, serta keterempilan yang diperlukan dirinya, masyarakat, Bangsa dan Negara (Pidarta, 2009).

Pendidikan adalah usaha yang sengaja diadakan baik langsung maupun dengan cara yang tidak langsung untuk membantu anak dalam perkembangan mencapai kedewasaannya (Ahamadi dkk, 1991). Sedangkan Belajar adalah proses perubahan tingkah laku berkat pengalaman dan latihan. Tanpa pengalaman dan latihan sangat sedikit proses belajar yang berlangsung. Pengalaman adalah suatu intraksi antara individu dengan lingkungan pengamatannya, dalam intraksi itulah individu belajar ia memperoleh pengertian, sikap, keterampilan, dan sebagainya. Mengajar adalah membimbing peserta didik belajar (Rohani, 2004).

Belajar adalah perubahan tingkah laku atau penampilan, dengan serangkaian kegiatan misalnya membaca, mengamati, mendengarkan, meniru dan sebagainya. Mengajar adalah suatu usaha untuk menciptakan kondisi atau sistem lingkungan yang mendukung dan memungkinkan untuk berlangsungnya proses belajar (Sardiman, 2010). Sedangkan menurut Ngalimun (2012) Metode adalah salah satu cara yang dipergunakan untuk mencapai tujuan pembelajaran yang telah ditetapkan.
Berdasarkan hasil observasi yang dilakukan di Sekolah Dasar Negeri 5 Bengkulu Tengah khususnya kelas VI, diketahui bahwa dalam hasil pembelajaran di kelas VI masih sangat rendah, dilihat dari hasil nilai rata-rata ujian pada mata pelajaran tahun pelajaran 2018/2019, sebanyak 35\% siswa yang mendapat nilai rendah yaitu dengan nilai rata-rata 65 dengan kreteria ketuntasa minimal (KKM) 75, Sedangkan proses belajar mengajar dikatakan tuntas secara klasikal apabila $85 \%$ dari siswa dikelas memperoleh nilai dengan Kriteria Ketuntasan Minimal (KKM) yakni 75. Guru sudah menerapkan berbagai sumber belajar seperti buku, carta, perpustakaan serta laboratorium dan metode cerama dalam pembelajaran hasilnya cukup optimal. Hal ini disebabkan oleh beberapa faktor yang membuatnya kurang begitu baik antara lain kurangnya minat siswa untuk belajar, mencatat dan mendengarkan materi yang di sampaikan. Untuk masalah tersebut dan meningkatkan hasil belajar siswa akan digunakan metode inkuiri.

Metode inkuiri merupakan metode yang menempatkan guru sebagai pembimbing atau fasilitator sehingga anak dituntut belajar mandiri dan melakukan kegiatan sendiri dalam menyelesaikan masalah-masalah secara ilmiah (Neni rusmawarni, 2009).

Adapun menurut Roestiyah (2001) dalam Rusmawarni (2009) pembelajaran inkuiri memiliki keunngulan sebagai berikut:

1. Dapat membantu dan mengembangkan "set concept" pada diri siswa sehingga siswa dapat mengerti tentang konsep dasr dari ide yang lebih baik.

2. Membantu dalam menggunakan ingatan dan transfer pada situasi proses belajar yang baru. 
3. Mendorong siswa untuk berpikir dan bekerja atas inisiatif sendiri, bersikap objektif, jujur, dan terbuka.

4. Memdorong siswa untuk berpikir intensitif dan merumuskan hipotesisnya sendiri.

5. Memberi kepuasan yang bersifat interinsik.

6. Situasi proses belajar menjadi lebih merangsang.

7. Dapat mengembangkan bakat atau kecakapan individu.

8. Memberi kebebasan pada siswa untuk belajar sendiri.

9. Siswa dapat menghindari cara belajar tradisional.

10. Dapat memberikan waktu pada siswa secukupnya sehingga mengasimilasikan dan mengkondisikan informasi.

Berdasarkan latar belakang diatas, sehingga dirasa perlu untuk dilakukan penelitian mengenai pemanfaatan lingkungan sekitar sekolah sebagai sumber belajar dengan metode inkuri untuk meningkatkan hasil belajar siswa SD Negeri 5 Bengkulu Tengah

\section{METODE PENELITIAN}

Desain penelitian yang digunakan dalam penelitian ini adalah Classroom Action Research (Penelitian Tindakan Kelas). Penelitian tindakan kelas adalah sebuah bentuk kegiatan refleksi diri yang dilakukan oleh para pelaku pendidikan dalam suatu situasi kependidikan untuk memperbaiki rasionalitas dan keadilan tentang: praktek kependidikan mereka, pemahaman mereka tenteng praktek tersebut, dan situasi dimana praktek tersebut dilakukan (Kunandar, 2011).

Penelitian ini dilakukan di SD Negeri 5

Bengkulu Tengah. Waktu penelitian dilaksanakan bulan Maret 2019. Adapun Subjek dalam penelitian ini adalah siswa kelas VI SD Negeri 5 Bengkulu Tengah. Penelitians tindakan kelas ini dilakukan dalam beberapa siklus dengan prosedur sebagai berikut :

1. Siklus I

a. Tahap Perencanaan ( Planing)

Pada tahapan perencanaan kegiatan ini disusun rencana yang akan dilakukan dengan beberapa tahap antara lain :

1. Menyusun skenario pembelajaran.

2. Menyusun Rencana Pelaksanaan Pembelajaran (RPP).

3. Merancang Skenario pembelajaran berdasarkan rencana pembelajaran melalui metode inkuiri.

4. Membuat lembaran observasi guru dan lembaran observasi siswa.

5. Membuat LKS.

6. Menyiapkan alat evaluasi.

b. Pelaksaan Tindakan (Action)

Kegiatan yang dilaksanakan dalam tahap ini adalah melaksanakan pembelajaran sesuai rencana pelaksanaan pembelajaran yang telah direncanakan dilakukan tindakan sebagai berikut :

1. Apersepsi dan motivasi

2. Menyampaikan konsep materi pelajaran

3. Menujukan topik peyelidikan

4. Menyajikan pertanyaan atau masalah

5. Membagi siswa dalam kelompok

6. Membagikan LKS

7. Membuat Hipotesis

8. Merencanakan Percobaan
9. Melakukan Percobaan Untuk Memperoleh Informasi 10. Mengumpulkan Dan Menganalisis Data

c. Tahap Observasi

Untuk mendapatkan data dari penelitian ini dilakukan obsevasi terhadap pelaksanaan tindakan atau aktivitas guru pada saat pembelajaran berlangsung dan terhadap aktivitas siswa pada saat mengikuti pembelajaran . Pelaksanaan kegiatan pada tahapan ini dengan bantuan lembar observasi aktivitas guru dan lembar observasi aktivitas siswa yang dilakukan oleh dua orang observer.

d. Refleksi

Peneliti mengidentifikasi hal-hal yang sudah tercapai dan belum tercapai pada siklus I sebagai acuan untuk melaksanakan perbaikan pada siklus II/III.

Siklus $n$

Siklus $n$ dilaksanakan setelah melihat refleksi pada siklus sebelumnya dan hasil refleksi tersebut dijadikan pedoman untuk melakukan perbaikanperbaikan pada siklus sebelumnya.

\section{A. Instrumen Penilaian}

1. Lembar Tes

Tes yang dilakukan dalam penelitian ini bertujuan untuk mengukur tingkat pencapaian atau hasil siswa terhadap materi pelajaran yang di sajikan. Adapn bentuk tes yang akan di gunakan adalah adalah pilihan ganda dan essay.

2. Lembaran Observasi

lembaran observasi digunakan untuk memperoleh data evaluasi proses belajar mengajar dengan menggunakan metode inkuiri, lembar observasi siswa dalam belajar dengan 12 aspek dalam kategori kurang, cukup dan baik. Lembar observasi guru dalam mengajar terdiri dari 12 aspek dalam katagori kurang, cukup dan baik. Lembar observasi guru digunakan untuk mengamati aktivitas guru dalam mengajar dan lembar observasi siswa digunakan untuk mengamati aktivitas siswa dalam proses pembelajaran.

\section{A. Prosedur Pengolahan dan Analisis Data \\ 1. Analisis Data Observasi}

Analisis data hasil obsevasi guru dan siswa. Data hasil observasi dianalisis dengan mendeskripsikan aktivitas guru dan siswa selama kegiatan pembelajaran berlangsung. Data yang diperoleh dengan mengunakan lembar observasi untuk setiap aspek yang diamati, katagori yang di gunakan Baik (B), Cukup (C), Kurang (K), seperti pada tabel dibawah ini:

Tabel 1. Skor pengamatan setiap aspek yang diamati pada lembar obsevasi guru dan siswa.

\begin{tabular}{c|c}
\hline Kategori & Skor \\
\hline B (Baik) & 3 \\
C (Cukup) & 2 \\
K (Kurang) & 1 \\
\hline
\end{tabular}

Dalam kegiatan observasi guru dan siswa di analisis dengan menghitung skor obsevasi dan menentukan katagori skor obsevasi berdasarkan kisaran kategori skor. Pada lembar observasi guru dan siswa 
terdapat 12 aspek yang diamati dengan jumlah kreteria penilaian 1 sampai 3. Jadi:

a. Sekor tertinggi $=$ jumlah aspek yang diamati $\mathrm{x}$ skor tertinggi tiap kreteria. Skor tertinggi $=1 \times 3=36$

b. Skor terendah $=$ Jumlah aspek yang diamati $\mathrm{x}$ skor terendah tiap kreteria. Skor terendah $=12 \times 1=12$

c. Rentang $=\frac{\text { skor tertinggi-skor terendah }}{\text { jumlah kreteria penilaian }}$

$=\frac{36-12}{3}=8$

Jadi untuk penentuan kriteria dapat dilihat pada tabel .2 berikut ini:

Tabel 2. Kisaran kriteria analisis data observasi guru dan siswa

\begin{tabular}{|c|c|c|}
\hline $\mathrm{NO}$ & Skor & Kriteria \\
\hline 1. & $12-20$ & Kurang \\
\hline 2. & $21-28$ & Cukup \\
\hline 3. & $29-36$ & Baik \\
\hline
\end{tabular}
dan Untuk mengetahui nilai rata-rata aktifitas guru dapat dihitung dengan cara menjumlahkan total skor dari pengamat pertama (P1) dan pengamat kedua (P2) kemudian dibagi menjadi dua. $\mathrm{X}=\frac{\sum P 1+\sum P 2}{2}$

Keterangan : $\quad X$ : Nilai rata-rata

$$
\begin{aligned}
& \sum^{p 1}: \text { Total skor pengamat pertama } \\
& \sum_{p 2} \text { : Total skor pengamat kedua }
\end{aligned}
$$

\section{Analisis Lembar Test}

Data dianalisis dengan rata-rata nilai yang diperoleh siswa dengan kreteria ketuntasan belajar. Tes ini digunakan untuk melihat atau memperoleh data tentang peningkatan hasil belajar untuk mengetahui tingkat persamaan siswa terhadap bahan agar dapat digunakan rumus ketuntasan belajar .

1. Data yang di peroleh dari hasil belajar siswa akan dianalisis dengan rumus presentase :

$$
P=\frac{f}{N} x 100 \%
$$

Keterangan :

$$
\text { (sudijono, 2004) }
$$

$P$ : Presentase

F : Frekuensi hasil belajar

$\mathrm{N}$ : Jumlah responden

$100 \%=$ konstanta (angka tetapan)

\section{HASIL PENELITIAN}

\section{A. Hasil Penelitian}

Berdasarkan penelitian yang dilakukan dalam III siklus pembelajaran menggunakan metode inkuiri dengan pemanfaatan lingkungan sekolah pada pembelajaran untuk meningkatkan aktivitas dan hasil belajar siswa kelas VI SD Negeri 5 Bengkulu Tengah di peroleh hasil sebagai berikut:

\section{Siklus 1}

a. Hasil Observasi Aktivitas Guru dan Siswa Siklus 1

Pada proses pembelajaran menggunakan

Metode Inkuiri dengan pemanfaatan ligkungan sekolah dilakukan pengamatan terhadap aktivitas guru dan siswa. Pada tahap observasi ini proses pembelajaran ini dilihat oleh 2 orang yang bertindak sebagai observer.

1) Deskripsi hasil observasi terhadap aktivitas guru

Hasil data observasi terhadap aktivitas guru pada siklus I yang sudah dilakukan 2 orang observer dapat diperoleh data seperti yang dilihat pada tabel 3 . dibawah ini:

Tabel 3. Data hasil observasi terhadap aktivitas guru pada siklus $\mathbf{I}$.

\begin{tabular}{cccc}
\hline Skor yang didapat & $\begin{array}{l}\text { Rata- } \\
\text { rata }\end{array}$ & Criteria \\
\cline { 1 - 2 } Pengamat I & Pengamat II & & \\
\hline 28 & 26 & 27 & Cukup
\end{tabular}

Dari tabel 5 dapat diketahui bahwa hasil data observasi yang telah dilakukan kedua pengamat dapat diketahui jumlah total skor 54 dengan rata-rata skor 27 sehingga dapat disimpulkan aktivitas guru termasuk dalam kriteria cukup. Bersasarkan hasil pengamatan dari kedua observer, masih ditemukan aspek yang harus diperbaiki antara lain:

a) Guru kurang menjelaskan informasi tentang materi pelajar.

b) Guru kurang membimbing siswa mengidentifikasi masalah.

c) Guru kurang membantu siswa membuat hipotesis.

d) Guru kurang membimbing siswa mengurutkan langkah-langkah percobaan.

e) Guru kurang mengarahkan siswa melakukan eksperimen untuk memecahkan permasalahan pada LKS.

f) Guru kurang memberikan kesempatan masingmasing kelompok untuk mempresentasikan hasil pengamatan/hasil diskusi di depan kelas.

g) Guru kurang melakukan Tanya jawab untuk membuat kesimpulan.

2) Deskripsi hasil observasi terhadap aktivitas siswa Penilaian aktivitas belajar siswa dilihat dari duabelas indikator pencapaian. Hasil data observasi terhadap aktivitas siswa pada siklus I yang dilakukan oleh dua observer dapat diperoleh data seperti yang dapat dilihat pada tabel 6 dibawah ini :

Tabel 4. Data hasil observasi terhadap aktivitas siswa pada siklus 1

\begin{tabular}{cccc}
\hline \multicolumn{2}{c}{ Skor yang didapat } & $\begin{array}{c}\text { Rata- } \\
\text { rata }\end{array}$ & Criteria \\
\cline { 1 - 2 } Pengamat I & $\begin{array}{c}\text { Pengamat } \\
\text { II }\end{array}$ & & \\
\hline 26 & 26 & 26 & Cukup
\end{tabular}

Berdasarkan table 4. diatas pada siklus I dapat diketahui bahwa aktivitas siswa selama mengikuti proses belajar mengajar menggunakan metode inkuiri dengan pemanfatan lingkungan sekolah diperoleh skor rata-rata 26 dapat disimpulkan bahwa aktivitas siswa berada dalam kriteria cukup dan masih perlu ditingkatkan. Siswa belum sepenuhnya melaksanakan aktivitas pembelajaran sesuai dengan langkah-langkah dalam proses pembelajaran menggunakan motode inkuiri. Hal-hal yang perlu diperbaiki antara lain: 
a) Siswa kurang mendengarkan dengan baik informasi tentang materi pelajaran.

b) Siswa kurang mendengarkan dan melaksanakan arahan yang disampaikan guru.

c) Siswa kurang memberikan pendapat untuk membuat hipotesis.

d) Siswa kurang mengurutkan langkah-langkah percobaan.

e) Siswa kurang serius melakukan eksperimen untuk memecahkan permasalah pada LKS.

f) Siswa kurang jelas mempresentasikan hasil pengamatan /hasil diskusi di depan kelas.

g) Siswa kurang aktif melakukan Tanya jawab untuk membuat kesimpulan .

\section{b. Hasil Belajar Siklus I}

Hasil belajar siswa berdasarkan nilai tes tertulis yang dilakukan diakhir proses pembelajaran dapat dilihat dalam tabel 7 dibawah ini:

Tabel 5. Data hasil belajar siswa siklus 1

\begin{tabular}{llll}
\hline $\begin{array}{l}\text { Jumlah siswa } \\
\text { yang } \\
\text { mendapat } \\
\text { nilai 75 keatas }\end{array}$ & $\begin{array}{l}\text { Nilai } \\
\text { Rata- } \\
\text { rata }\end{array}$ & $\begin{array}{l}\text { Persentase } \\
\text { ketuntasan } \\
\text { belajar } \\
\text { klasikal }\end{array}$ & $\begin{array}{l}\text { kriteria } \\
\text { ketuntasan } \\
\text { belajar } \\
\text { klasikal }\end{array}$ \\
\hline 17 & 71,15 & $65,38 \%$ & $\begin{array}{l}\text { Belum } \\
\text { Tuntas }\end{array}$ \\
\hline
\end{tabular}

Tabel 5 menunjukkan bahwa siswa yang tuntas mencapai KKM (Krikeria Ketuntasan Minimal) adalah 17 siswa dengan nilai rata-rata 71,15 dan persentase ketuntasan belajar kelasikal $65,38 \%$. Berdasarkan hasil tes tersebut maka hasil belajar dapat di katakan belum tuntas. Dari data tersebut menunjukkan bahwa siswa mulai antusias mengikuti pembelajaran meskipun masih ada beberapa siswa yang belum tuntas dalam proses pembelajaran menggunakan metode inkuiri.

\section{c. Refleksi siklus 1}

Berdasarkan hasil pengamatan, diperoleh refleksi pembelajaran sebagai berikut :

1). Aktivitas guru

a) Guru harus lebih maksimal menyajikan dan menjelas informasi tentang materi pelajar.

b) Guru harus lebih maksimal membimbing siswa mengidentifikasi masalah.

c) Guru harus membantu siswa membuat hipotesis.

d) Guru harus lebih maksimal membimbing siswa mengurutkan langkah-langkah percobaan.

e) Guru harus lebih maksimal mengarahkan siswa melakukan eksperimen untuk memecahkan permasalahan pada LKS.

f) Guru harus memberikan kesempatan masing-masing kelompok untuk mempresentasikan hasil pengamatan/hasil diskusi di depan kelas.

g) Guru harus melakukan Tanya jawab untuk membuat kesimpulan.

2). Aktivitas siswa

a) Siswa harus mendengarkan dengan baik informasi tentang materi pelajari.

b) Siswa harus mendengarkan dan melaksanakan arahan yang disampaikan guru.

c) Siswa harus lebih aktif memberikan pendapat untuk membuat hipotesis. d) Siswa harus mengurutkan langkah-langkah percobaan.

e) Siswa harus lebih serius melakukan eksperimen untuk memecahkan permasalah pada LKS.

f) Siswa harus lebih jelas mempresentasikan hasil pengamatan /hasil diskusi di depan kelas.

g) Siswa harus lebih aktif melakukan Tanya jawab dan mampu menyimpulkan materi pembelajaran yang telah di pelajari.

3). Ketuntasan klasial belum tercapai karena ketuntasan klasial baru mencapai 65,38\%.

Mencermati berbagai kekurangan yang ditemukan pada siklus I ini maka perlu ditindak lanjuti lagi dengan penelitian siklus II. Hasil refleksi ini bertujuan sebagai dasar untuk memperbaiki proses pembelajaran pada siklus selanjutnya.

\section{Siklus II}

a. Hasil Observasi Aktivitas Guru dan Siswa Siklus II

1) Deskripsi hasil observasi terhadap aktivitas guru Pada siklus II hasil observasi terhadap aktivitas guru dapat di peroleh data seperti yang dapat dilihat pada tabel 8 dibawah ini :

Tabel 6. Data hasil observasi terhadap aktivitas guru pada siklus II.

\begin{tabular}{lcll}
\hline \multicolumn{2}{l}{ Skor yang didapat } & Rata-rata & Criteria \\
\cline { 1 - 2 } Pengamat I & Pengamat II & \\
\hline 30 & 30 & 30 & Baik
\end{tabular}

Dari tabel 6 diatas dapat diketahui bahwa hasil data observasi yang telah dilakukan kedua pengamat di peroleh jumlah total skor 60 dengan rata-rata skor 30 sehingga dapat disimpulkan aktivitas guru termasuk dalam kriteria baik. Meskipun aktivitas guru pada siklus II ini dinyatakan baik, namun masih ada beberapa aspek yang mendapatkan nilai cukup. Adapun aspek yang harus di perbaiki antara lain:

a) Guru kurang membimbing siswa mengidentifikasi masalah.

b) Guru kurang mengarahkan siswa memberikan pendapat untuk membuat hipotesis.

c) Guru kurang membantu siswa membuat hipotesis.

d) Guru kurang membimbing siswa mengurutkan lankah-langkah percobaan.

e) Guru kurang melakukan Tanya jawab untuk membuat kesimpulan.

2) Deskripsi hasil observasi terhadap aktivitas siswa Hasil data observasi terhadap aktivitas siswa pada siklus II yang sudah dilakukan dua orang observer dapat diperoleh data seperti yang dapat dilihat pada tabel 9 dibawah ini:

Tabel 7. Data hasil observasi terhadap aktivitas siswa pada siklus II

\begin{tabular}{cccc}
\hline Skor yang didapat & Rata-rata & Criteria \\
\cline { 1 - 1 } Pengamat I & Pengamat II & \\
\hline
\end{tabular}




$\begin{array}{llll}30 & 28 & 29 & \text { Baik }\end{array}$

Dari tabel 7 pada siklus II dapat diketahui bahwa hasil data observasi yang telah dilakukan kedua pengamat dapat di ketahui jumlah total skor 58 dengan rata-rata skor 29 sehingga dapat disimpulkan aktivitas siswa berada dalam kriteria baik. Aktivitas siswa dalam proses pembelajaran menggunakan metode inkuiri secara umum sudah berjalan dengan baik, hal-hal yang perlu diperbaiki antara lain:

a) Siswa kurang memberikan pendapat untuk membuat hipotesis.

b) Siswa kurang mendengarkan arahan yang disampaikan guru untuk membuat hipotesis .

c) Siswa kurang serius melakukan eksperimen untuk memecahkan permasalahan pada LKS.

d) Siswa kurang melakukan Tanya jawab untuk membut kesimpulan.

b. Hasil Belajar Siklus II

Hasil belajar siswa berdasarkan nilai tes tertulis yang di lakukan diakhir proses pembelajaran dapat di lihat pada tabel 10 di bawah ini:

Tabel 8. Data hasil belajar siswa siklus II

\begin{tabular}{cccc}
\hline $\begin{array}{c}\text { Jumlah } \\
\text { siswa yang } \\
\text { mendapat } \\
\text { nilai } 75 \\
\text { keatas }\end{array}$ & $\begin{array}{c}\text { Nilai } \\
\text { Rata-rata }\end{array}$ & $\begin{array}{c}\text { Persentase } \\
\text { ketuntasan } \\
\text { belajar } \\
\text { klasikal }\end{array}$ & $\begin{array}{c}\text { kriteria } \\
\text { ktuntasan } \\
\text { belajar } \\
\text { klasikal }\end{array}$ \\
\hline 20 & 74.81 & $76.92 \%$ & $\begin{array}{c}\text { Belum } \\
\text { Tuntas }\end{array}$ \\
\hline
\end{tabular}

Tabel 8 menunjukkan bahwa siswa yang tuntas mencapai KKM (Krikeria Ketuntasan Minimal) adalah 20 siswa dengan nilai rata-rata 74,81 dan persentase ketuntasan klasikal $76,92 \%$. Berdasarkan hasil tes nilai rata-rata dan persentase ketuntasan belajar siswa pada siklus II ini sudah mengalami peningkatan dari siklus I tetapi masih belum dikatakan tuntas.

\section{c. Refleksi siklus II}

Berdasarkan hasil pengamatan, diperoleh refleksi pembelajaran sebagai berikut :

1) Aktivitas guru

a) Guru harus lebih maksimal membimbing siswa mengidentifikasi masalah.

b) Guru harus lebih maksimal mengarahkan siswa mengeluarkan pendapat untuk membuat hipotesis.

c) Guru harus membantu siswa membuat hipotesis.

d) Guru harus lebih maksimal membimbing siswa mengurutkan lankah-langkah percobaan.

e) Guru harus lebih maksimal melakukan Tanya jawab untuk membuat kesimpulan.

2) Aktivitas siswa

a) Siswa harus mengeluarkan pendapat untuk membuat hipotesis.

b) Siswa harus lebih optimal mendengarkan arahan yang disampaikan guru untuk membuat hipotesis.

c) Siswa harus lebih serius melakuka eksperimen untuk memecahkan permasalahan pada LKS.

d) Siswa harus lebih aktif melakukan tanya jawab untuk membut kesimpulan.

3) Hasil belajar siswa mengalami peningkatan pada siklus II ini meskipun ketuntasan klasial belum tercapai. Siswa yang telah mencapai KKM (Kriteria Ketuntasan Minimal) adalah 20 orang dengan nilai rata-rata 74,81 .

Berdasarkan hasil refleksi siklus II tersebut dapat disimpulkan bahwa indikator penelitian tindakan ini yang menyatakan bahwa penelitian ini dikatakan mengalami peningkatan mesipun belum tuntas. Hal ini ditunjukkan bahwa persentase ketuntasan belajar klasial pada siklus ini adalah $76,92 \%$.

\section{Siklus III}

a. Hasil Observasi Aktivitas Guru dan Siswa Siklus III

Pada proses pembelajaran menggunakan metode inkuiri dengan pemanfaatan lingkungan dilakukan pengamatan terhadap aktivitas guru dan siswa dengan menggunakan lembar observasi. Pada tahap observasi ini proses pembelajaran dilihat oleh dua orang yang bertindak sebagai observer.

\section{Deskripsi hasil observasi terhadap aktivitas guru} Berdasarkan hasil observasi terhadap aktivitas guru selama proses pembelajaran yang dilakukan oleh dua orang observer diperoleh data seperti yang dapat dilihat pada tabel 9 dibawah ini :

Tabel 9. Data hasil observasi terhadap aktivitas guru pada siklus III.

\begin{tabular}{cccc}
\hline \multicolumn{2}{c}{ Skor yang didapat } & \multirow{2}{*}{ Rata-rata } & Kriteria \\
\cline { 1 - 2 } Pengamat I & Pengamat II & & \\
\hline 34 & 34 & 34 & Baik
\end{tabular}

Dari tabel 9 dapat diketahui bahwa hasil data observasi kedua pengamat pada aktivitas guru dapat diketahui jumlah skor total 64 dengan rata-rata skor 34 sehingga dapat disimpulkan aktivitas guru termasuk kriteria baik. Dari tabel diatas juga dapat diketahui bahwa rata-rata aktivitas guru meningkat dari siklus I yaitu 27 , siklus II yaitu 30 dan siklus III menjadi 34 . Berdasarkan hasil pengamatan dari kedua observer, masih ditemukan aspek yang masih mendapatkan nilai cukup. Adapun aspek yang harus diperbaiki amtara lain:

a) Guru kurang membimbing siswa mengurutkan lankah-langkah percobaan.

b) Guru kurang melakukan Tanya jawab untuk membuat kesimpulan.

\section{Deskripsi hasil observasi terhadap aktivitas siswa}

Dari hasil observasi terhadap aktivitas siswa yang dilakukan oleh dua orang observer diperoleh data seperti yang dapat dilihat pada tabel 10 dibawah ini:

Tabel 10. Data hasil observasi terhadap aktivitas siswa pada siklus III

Skor yang didapat Rata-rata $\quad$ Criteria

\footnotetext{
Pengamat I Pengamat II
} 


\begin{tabular}{ccccc}
\hline 32 & 30 & & 31 & \multicolumn{2}{l}{ Baik } \\
\hline Berdasarkan tabel & 10 & pada & siklus & III dapat
\end{tabular}

Berdasarkan tabel 10 pada siklus III dapat diketahui bahwa aktivitas siswa dengan total skor 62 dengan rata-rata skor 31 sehingga dapat disimpulkan bahwa aktivitas siswa berada dalam kriteria baik. Pada siklus III ada beberapa aspek yang masih mendapatkan nilai cukup. Hal-hal yang perlu diperbaiki antara lain:

a) Siswa kurang mendengarkan arahan yang disampaikan guru untuk membuat hipotesis.

b) Siswa kurang serius melakukan eksperimen untuk memecahkan permasalahan pada LKS.

c) Siswa kurang melakukan Tanya jawab untuk membut kesimpulan.

\section{b. Hasil Belajar Siklus III}

Hasil belajar siswa berdasarkan nilai tes tertulis yang dilakukan diakhir proses pembelajaran dapat dilihat dalam tabel 13 dibawah ini:

\section{Tabel 13. Data hasil belajar siswa siklus III}

\begin{tabular}{cccc}
\hline $\begin{array}{c}\text { Jumlah } \\
\text { siswa yang } \\
\text { mendapat } \\
\text { nilai } 75 \\
\text { keatas }\end{array}$ & $\begin{array}{c}\text { Nilai } \\
\text { Rata- } \\
\text { rata }\end{array}$ & $\begin{array}{c}\text { Persentase } \\
\text { ketuntasan } \\
\text { belajar } \\
\text { klasikal }\end{array}$ & $\begin{array}{c}\text { kriteria } \\
\text { ktuntasan } \\
\text { belajar } \\
\text { klasikal }\end{array}$ \\
\hline 23 & 80,00 & $88,46 \%$ & Tuntas \\
\hline
\end{tabular}

Tabel 13 menunjukkan bahwa siswa yang tuntas mencapai KKM (Krikeria Ketuntasan Minimal) adalah 23 siswa dengan nilai rata-rata 80,00 dan persentase ketuntasan klasikal $88,46 \%$. Berdasarkan hasil tes tersebut maka terjadi peningkatan hasil belajar yang baik. Rata-rata hasil belajar siswa pada siklus III ini telah mencapai keberhasilan. Ketercapaian ketuntasan klasial ini disebabkan oleh peningkatan aktivitas guru dan aktivitas belajar siswa pada saat proses pembelajaran.

\section{c. Refleksi siklus III}

Berdasarkan hasil pengamatan, diperoleh refleksi pembelajaran sebagai berikut :

1).Aktivitas guru

a) Guru harus lebih maksimal membimbing siswa mengurutkan lankah-langkah percobaan.

b) Guru harus lebih optimal melakukan Tanya jawab untuk membuat kesimpulan.

2).Aktivitas siswa

a) Siswa harus lebih maksimal mendengarkan arahan yang disampaikan guru untuk membuat hipotesis.

b) Siswa harus lebih serius melakukan eksperimen untuk memecahkan permasalahan pada LKS.

c) Siswa harus lebih aktif melakukan Tanya jawab untuk membut kesimpulan.

2). Hasil belajar siswa mengalami peningkatan pada siklus III ini ketuntasan klasial telah tercapai. Siswa yang telah mencapai KKM (Kriteria Ketuntasan Minimal) adalah 23 siswa dengan nilai rata-rata 80,00 dan pesentase ketuntasan belajar klasikal $88,46 \%$.

Berdasarkan hasil refleksi siklus III tersebut dapat disimpulkan bahwa indikator penelitian tindakan ini yang menyatakan bahwa penelitian ini dikatakan baik. Hal ini ditunjukkan ketuntasan belajar klasial pada siklus ini sebesar $88,64 \%$.

\section{B. Deskripsi Antar Siklus}

Berdasarkan hasil analisis yang dilakukan pada siklus I, II dan III dapat dibuat perbandingan sebagai berikut:

a.Hasil observasi aktivitas guru dan siswa

Tabel 14. Hasil Perbandingan tingkat aktivitas guru dan siswa setiap siklus

\begin{tabular}{cllll}
\hline Siklus & \multicolumn{4}{c}{ skor observasi } \\
\cline { 2 - 5 } & $\begin{array}{l}\text { Guru } \\
\text { rata-rata } \\
\end{array}$ & & $\begin{array}{l}\text { Siswa } \\
\text { rata-rata }\end{array}$ & Criteria \\
& skor & kriteria & skor & \\
1 & Guru & Siswa & Guru & Siswa \\
2 & Guru & Siswa & Guru & Siswa \\
3 & Guru & Siswa & Guru & Siswa \\
\hline
\end{tabular}

Tabel 14 di atas menunjukkan bahwa untuk tingkat aktivitas guru dan siswa mengalami peningkatan setiap siklusnya. Hal ini bisa dilihat pada siklus I untuk aktivitas guru skor rata-rata di dapat 27 menjadi 30 pada siklus II dan menjadi 34 pada siklus III. Begitupun untuk tingkat aktivitas siswa pada siklus I didapat skor rata-rata sebesar 26 menjadi 29 pada siklus II dan menjadi 31 pada siklus III. Peningkatan ini disebabkan karena siswa mulai terbiasa menggunakan metode inkuiri dengan pemanfaatkan lingkungan sekolah, sehingga ketika proses pembelajaran berlangsung siswa sudah tidak terlihat kebinggungan lagi dan interaksi antara guru dengan siswa terlaksana dengan baik, maupun antar siswa semakin intensif.

\section{b. Hasil Belajar siswa}

Hasil belajar siswa menggambarkan keterserapan materi pelajaran yang di ukur dengan tes evaluasi hasil belajar atau tes siklus, dimana nilai tes ini akan menentukan ketuntasan belajar siswa dalam penelitian ini. Pada siklus III terdapat $88,64 \%$ siswa yang telah mencapai KKM, berarti untuk ketuntasan hasil belajar dalam satu kelas telah tercapai. Secara terperinci peningkatan setiap siklusnya seperti tabel dibawah ini.

Tabel 15. Presentase Peningkatan Hasil Belajar Berdasarkan Nilai Tes Siklus

\begin{tabular}{ccccc}
\hline No & $\begin{array}{c}\text { Jumlah } \\
\text { siswa }\end{array}$ & $\begin{array}{c}\text { Nilai rata- } \\
\text { rata kelas }\end{array}$ & \multicolumn{2}{c|}{ siswa yang tuntas } \\
\hline & & & Jumlah & Persen (\%) \\
\hline 1 & 26 & 71,15 & 17 & $65,38 \%$ \\
2 & 26 & 74,81 & 20 & $76,92 \%$ \\
3 & 26 & 80,00 & 23 & $88,64 \%$ \\
\hline
\end{tabular}

Tabel 15 diatas menunjukkan bahwa pada siklus I ketuntasan klasial baru 65,38\%, pada sikus II meningkat menjadi $76,92 \%$, pada siklus III terjadi peningkatan kembali $88,64 \%$. Peningkatan hasil belajar tersebut disebabkan oleh peningkatan kualitas proses pembelajaran. Siswa sudah bisa menerima proses pembelajaran menggunakan metode inkuiri dengan pemanfaatan lingkungan sekolah diruangan maupun di luar ruangan. Dalam proses pembelajaran tersebut guru berperan sebagai fasilitator dan pembimbing siswa.

\section{Pembahasan}


Dari hasil penelitian yang telah dilaksanakan menggunakan metode inkuiri dengan pemanfaatan lingkungan sekolah dalam tiga siklus pada pokok bahasan Lingkungan ternyata dapat meningkatkan aktivitas dan hasil belajar siswa kelas VI SD Negeri 5 Bengkulu Tengah. Masing-masing siklus terdiri dari beberapa tahap yaitu tahap perencanaan, tahap tindakan, tahap observasi dan tahap refleksi.

Proses pembelajaran dilakukan dalam tiga siklus diperoleh data-data yang menunjukkan terjadinya peningkatan dari siklus I, siklus II ke siklus III, baik itu peningkatan pada aktivitas guru dan siswa maupun hasil belajar siswa. Berdasarkan peningkatan tersebut dapat dikatakan bahwa dalam proses pembelajaran menggunakan metode inkuiri dengan memanfaatkan lingkungan dapat meningkatkan aktivitas guru dan siswa serta hasil belajar siswa.

\section{Peningkatan Aktivitas \\ a. Aktivitas Guru}

Berdasarkan hasil analisis terhadap aktivitas guru pada siklus I tergolong dalam kriteria cukup dimana nilai skor observasinya adalah 28 pada pengamat I dan skor 26 pada pengamat II dengan rata-rata skor 27. Hasil analisis terhadap aktivitas guru pada siklus II tergolong ke dalam kriteria baik dimana nilai skor observasinya adalah 30 pada pengamat I dan skor 30 pada pengamat II dengan rata-rata skor 30 . sedangkan untuk hasil analisis terhadap aktivitas guru pada siklus III tergolong ke dalam kriteria baik dimana nilai skor observasinya adalah 34 pada pengamat I dan skor 34 pada pengamat II dengan rata-rata skor 34 .

Peningkatan aktivitas guru pada setiap siklus terjadi karena pembelajaran menggunakan metode inkuiri dengan femanfaatan lingkungan, guru dituntut untuk lebih aktif dalam membimbing siswa dan memberikan pengarahan yang cukup sehingga guru dapat berperan sebagai fasilitator dalam melaksanakan proses pembelajaran di ruangan maupun di luar ruangan. Hal ini di dukung oleh pendapat Rusmawarni (2014) menyatakan bahwa metode yang dapat mengembangkan peran guru sebagai pembimbing dan fasilitator sehingga anak dituntut secara mandiri dan melakukan kegiatan sendiri dalam menyelesaikan masalah-masalah secara ilmiah yaitu metode inkuiri.

Dengan demikian dapat disimpulkan bahwa pembelajaran menggunakan metode inkuiri dengan pemanfaatan lingkungan sekolah dapat meningkatkan aktivitas guru dalam proses pembelajaran.

\section{b. Aktivitas Siswa}

Berdasarkan hasil analisa observasi aktivitas siswa selama proses pembelajaran berlangsung menggunakan metode inkuiri dengan pemanfaatan lingkungan sekolah yang dilakukan oleh dua orang pengamat pada siklus I, siklus II dan siklus III terlihat adanya peningkatan aktivitas siswa di dalam proses pembelajaran. Pada siklus I aktivitas siswa memperoleh skor 26 pada pengamat I dan skor 26 pada pengamat II, dengan rata-rata skor 26 dan masih tergolong kriteria cukup. Pada siklus II hasil analisis aktivitas siswa memperoleh skor 30 pada pengamat I dan skor 28 pada pengamat II, dengan rata-rata skor 29 dan tergolong kriteria baik. Sedangkan pada siklus III hasil analisis aktivitas siswa memperoleh skor 32 pada pengamat I dan skor 31 pada pengamat II, dengan rata-rata skor 31 dan tergolong ke dalam kriteria baik.

Peningkatan aktivitas siswa pada setiap siklus terjadi karena pembelajaran menggunakan metode inkuiri dengan femanfaatan lingkungan, siswa dituntut untuk berpikir dan bekerja keras atas inisiatip sendiri dalam melakukan eksperimen di lingkungan sekolah untuk menemukan jawaban dari permasalah yang ingin di selesaikan, siswa juga dituntut untuk merumuskan hipotesis sendiri serta diberikan kebebasa untuk belajar sendiri agar dapat mengembangkan potensi dan proses belajar siswa. Seperti yang diuraikan Rusmawati (2009) yang menyatakan metode inkuiri memiliki keunggulan/kelebihan sebagai berikut: Mendorong siswa untuk berpikir dan bekerja atas inisiatif sendiri, bersikap objektif, jujur, dan terbuka serta Memdorong siswa untuk berpikir intensitif dan merumuskan hipotesisnya sendiri dan Memberi kebebasan pada siswa untuk belajar sendiri.

Dan diperkuat oleh pendapat (Agustatin, 2012) pembelajaran yang persiapan situasi bagi anak untuk melakukan eksperimen sendiri dan mencari jawaban atas pertanyaan sendiri, menghubungkan penemuan satu dengan penemuan yang lain, memandingkan yang ditemukan sendiri dengan yang ditemukan orang lain adalah metode inkuiri.

Dengan demikian dapat disimpulkan bahwa pembelajaran menggunakan metode inkuiri dengan pemanfaatan lingkungan sekolah dapat meningkatkan aktivitas siswa dalam proses pembelajaran.

\section{Peningkatan Hasil belajar Siswa}

Berdasarkan hasil penelitian yang sudah dilakukan melalui metode inkuiri dengan pemanfaatan lingkungan sekolah dalam tiga siklus pada pembelajaran dikelas VI SD Negeri 5 Bengkulu Tengah yang berjumlah 26 siswa, diketahui mengalami peningkatan hasil belajar pada penelitian dari siklus I, siklus II dan siklus III. Pada siklus I diketahui nilai rata-rata siswa 71,15 dengan jumlah siswa yang tuntas yaitu 17 siswa dari 26 siswa dan presentase ketuntasan belajar klasikal 65,38\% siswa. Karena, berdasarkan KKM SD Negeri 5 Bengkulu Tengah yaitu suatu kelas dikatakan tuntas apabila nilai rata-rata siswa mendapat 75 keatas dengan presentase $85 \%$, berdasarkan ketentuan tersebut maka pada siklus I belum dikatakan tuntas.

Pada hasil nilai siklus II mengalami peningkatan dengan skor nilai rata-rata siswa mencapai 74,81 dengan jumlah siswa yang tuntas 20 orang dari 26 orang dan presentase ketuntasan belajar klasikal 76,92\%. Karena, berdasarkan KKM SD Negeri 5 Bengkulu Tengah yaitu suatu kelas dikatakan tuntas apabila nilai rata-rata siswa mendapkan 75 keatas dengan presentase $85 \%$, berdasarkan ketentuan tersebut maka pada siklus II belum dikatakan tuntas.

Pada siklus III mengalami peningkatan kembali dengan skor nilai rata-rata siswa mencapai dengan jumlah siswa yang tuntas dari 23 orang dan presentase ketuntasan belajar adalah menjadi $88,64 \%$. Berdasarkan KKM SD Negeri 5 Bengkulu Tengah suatu kelas dikatakan tuntas apabila nilai rata-rata siswa mendapat 
75 keatas dengan presentase $85 \%$, berdasarkan ketentuan tersebut maka pada siklus III sudah tuntas karena sudah lebih dari $85 \%$ siswa yang mendapatkan nilai 75 keatas.

Jika dilihat dari hasil belajar tersebut menunjukkan bahwa pembelajaran biologi menggunakan metode inkuiri dengan pemanfaatan lingkungan sekolah dapat meningkatkan hasil belajar siswa. Peningkatan hasil belajar tersebut disebabkan oleh proses belajar yang lebih merangsang, membantu dalam menggunakan ingatan dan dapat mengembangkan bakat atau kecakapan individu, suasana belajar tampak terarah saat siswa terlihat aktif melakukan pengamatan di lingkunagn sekolah guna memecahkan sendiri permasalah pembelajaran, pada pembelajaran seperti ini siswa juga dilatih untuk meningalkan cara belajar secara teradisional. Hal ini diperkuat dengan pendapat Roestiyah dalam Rusmawati (2009) yang menyatakan metode inkuiri memiliki keunggulan atau kelebihan sebagai berikut:

1. Dapat membantu dan mengembangkan "set concept" pada diri siswa sehingga siswa dapat mengerti tentang konsep dasar dari ide yang lebih baik.

2. Membantu dalam menggunakan ingatan dan transfer pada situasi proses belajar yang baru.

3. Memberi kepuasan yang bersifat interinsik.

4. Situasi proses belajar menjadi lebih merangsang.

5. Dapat mengembangkan bakat atau kecakapan individu.

6. Siswa dapat menghindari cara belajar tradisional.

\section{KESIMPULAN}

A. Kesimpulan

Akhirnya, penulis dapat memperoleh beberapa hasil temuan setelah melaksanakan refleksi dan diskusi pada bab sebelumnya dan Penelitian Tindakan Kelas ini dapat disimpulkan sebagai berikut:

1. Pembelajaran menggunakan metode inkuiri dengan pemanfaatan lingkungan sekolah dapat meningkatkan aktifitas guru dan siswa. Hal ini dapat dilihat dari hasil observasi yang menunjukan persentase aktivitas guru pada siklus I hanya mencapai 27 pada siklus II mencapai 30 dan pada siklus III mencapai 34, sedangkan untuk aktivitas siswa pada siklus I mencapai 26 pada siklus II mencapai 29 dan pada siklus III menjadi 31.

2. Pembelajaran menggunakan metode inkuiri dengan pemanfaatan lingkungan sekolah ini dapat meningkatkan hasil belajar siswa. Hal ini terlihat dari hasil nilai persentase ketuntasan Klasikal pada siklus I hanya mencapai $65,38 \%$ pada siklus II mencapai $76,92 \%$ dan pada siklus III menjadi $88,64 \%$.

\section{DAFTAR PUSTAKA}

Ahmadi, Abu Dan Ubhiyati, Nur. 1991. Ilmu Pendidikan. Rineka Cipta. Jakarta.

Agustanti, T.H. 2012. Emplementasi Metode Inquiri Untuk Meningkatkan Hasil Belajar. Diaksis dari: http://journal.unnes.ac.id/index.php/jpii. $\quad 4$ Januari 2015.

Dimyati dan Mudjiono. 2009. Belajar Dan Pembelajaran. Rineka Cipta. Jakarta.

Kunandar. 2011. Langkah Mudah Penelitian Tindakan Kelas Sebagai Pengembangan Profisi Guru. Rajawali Pres. Jakarta.

Majid, Abdul. 2008. Perencanaan Pembelajaran. Remaja Rosdakarya. Bandung.

Ngalium. 2012. Strategi Dan Model Pembelajaran. Aswaja Pressindo. Banjarmasin.

Pidarta, Made. 2009. Landasan Kependidikan. Rineka Cipta. Jakarta.

Rohani, Ahmad. 2004. Pengolaan Pengajaran. Rineka Cipta. Jakarta.

Suharnni, Neni. 2009. Penerapan Metode Inkuiri Dalam Meningkatkan Prestasi Siswa Pad Mata Pelajaran Biologi Kelas VII A SMPN 7 Bengkulu Selatan. UMB. Bengkulu.

Sagala, Syaiful. 2008. Konsep Dan Makna Pembelajaran. Alfabeta Cv. Bandung.

Sadirman. 2010. Interaksi Dan Motivasi Belajar Mengajar. Rajawali Pers. Jakarta.

Samsudin. 2010. Pemanfaatan Lingkungan Sekitar Sekolah Sebagai Sumber Belejar Biologi Pada Pokok Bahasan Keanekaragaman Makhluk Hidup Untuk Meningkatkan Prestasi Belajar Siswa Kelas VII A SMPN No 02 Kerkap Bengkulu Utara. UMB. Bengkulu.

Sudijono, A. 2004. Pengantar Evaluasi pendidikan Rajawali Prest. Jakarta.

Tampubolon, Saur M. 2014. Penelitian Tindakan Kelas. Erlangga. Jakarta.

Trianto. 2007. Model-Model Pembelajaran Inovatif Berorentasi Konstruktivitas. Prestas Pustaka. Jakarta. 